\title{
Boko Haram in the Nigerian press: the politics of labelling
}

Mercy Ette \& Sarah Joe

Department of Media, Journalism and Film

University of Huddersfield.

\begin{abstract}
Labels shape and define public discourse. As condensational symbols, they can serve as political tools and instruments of policy due to the media's tendency to use labels to create meaning and knowledge about political and social reality. This study examines the politics of labelling through a case study of the representation of Boko Haram in a selection of Nigerian national newspapers. Boko Haram, a transnational terrorist organisation responsible for the death of over 20,000 Nigerians and the displacement of more than two million people, has been a major threat to the Nigerian state for almost a decade. Although it was originally perceived to be a domestic problem, its reach across national boundaries has extended its impact beyond Nigeria and it has now been recognised as an international threat. This paper explores how labels used to frame this group in the Nigerian press echo geoethno polarities embedded in Nigerian politics. The study investigates the representations of Boko Haram to evaluate how the narrative about the sect has been constructed. It reveals that the dominant voices prefer labels such as terrorists and insurgents, which reflect popular understanding of the sect. Through a content analysis of a selection of national news stories, the study argues that the nature of Nigerian politics and media ecology plays a critical role in the media framing of Boko Haram.
\end{abstract}

\section{Keywords}

Boko Haram, labelling, Nigeria, terrorism, Nigerian newspapers, political violence

\section{Introduction}

In December 2011, a sub-committee of the United States House of Representatives Committee on Homeland Security issued a report that identified Boko Haram as an 'emerging threat to the U.S. Homeland'. The report designated Boko Haram as 'an Islamist religious sect turned insurgent group based in the predominantly Muslim northern Nigeria' and underlined the group's 'potential to commit acts of terrorism against U.S. interests and the U.S. homeland' (Committee on Homeland Security report, 2011:5). In addition, the subcommittee recommended 'an investigation into whether Boko Haram should be categorised as a Foreign Terrorist Organisation' (FTO) and argued that identifying the group as a FTO would empower the United States intelligence and law enforcements communities to ensure the group 'does not 
attack US interests and the US mainland' (Committee on Homeland Security report, 2011:3).

Using the Homeland Security Committee's report as a point of departure, this study examines labels used by different actors in the framing of Boko Haram in a selection of Nigerian national newspapers. It explores how the selected newspapers constructed narratives about Boko Haram through the use of labels provided by political actors and the publications themselves. We argue that popular labels used in the Boko Haram discourse such as insurgents and criminals serve as foci that evoke particular understanding of the group. Furthermore, by identifying both labels and political actors who use them in newspaper narratives about Boko Haram, a group whose activities threaten the existence of the Nigerian state, the study highlights the power relations embedded in the politics of labelling.

\section{Boko Haram: What's in a name?}

Boko Haram is a transnational terrorist organisation that has been a major threat to the Nigerian state for almost a decade. It has been accused of being responsible for the death of over 20,000 Nigerians and the displacement of more than two million people. As the 2011 US Homeland Security Committee's report states, 'the origins of Boko Haram are murky'. Some commentators suggest it has been in existence since the late 1990 s or early 2000 s. Andrew Walker, a freelance journalist with extensive experience of covering Nigeria, associates Boko Haram with a radical Islamist group that was formed in 2002 in Maiduguri, in north-eastern Nigeria. The group initially emerged as a social welfare and educational support project that provided a safety net for members of its community. It filled a vacuum created by an absent state that had failed to meets its social responsibilities to citizens (Walker, 2012). Farouk Chothia, writing for the BBC African Service, noted that the group ran an Islamic school that catered for children from 'many poor Muslim families from across Nigeria' (Chothia, 2016). However, over time, the group transmuted into an extremist organisation and has now expanded beyond north-eastern Nigeria into neighbouring countries of Cameroon, Chad and Niger. Its trajectory of violence includes spates of violent attacks against security forces, and civilians in parts of northern Nigeria; the bombing of the UN House, Abuja, in 2011; the kidnapping in 2014 of almost 300 girls from a secondary school in Chibok, north-eastern Nigeria, and numerous other acts of violence. In 2013, Boko Haram was recognised as a terrorist group by the US State Department, alongside organisations such as AI Qaeda, Hamas, and the Real Irish Republican Army (Labott and Botelho, 2013).

The evolution of a non-violent community support group into an extremist organisation that uses violence as a strategy to propagate an Islamic ideology and destabilise Nigeria has been attributed to a variety of factors. The US Homeland Security Committee's report, for example, suggested that the emergence of a radical Islamic group in Nigeria was a product of 'a feeling of alienation from the wealthier, Christian, oil-producing, southern Nigeria, pervasive poverty, rampant government corruption, heavy-handed security measures, and the belief that relations with the West are a corrupting influence' (US Homeland Security Committee Report, 2011:6). Jean Herskovits, a professor of history at the State University of New York, asserts that Boko Haram was a peaceful Islamic splinter group when it emerged in 2002 but became radical when 'politicians began exploiting it for electoral purposes' (Herskovits, 2012). 
The mutation of Boko Haram can also be seen as a direct product of the decadent nature of governance in Nigeria, championed by self-seeking prebendalists, and evidenced in the high incidence of corruption and ever-increasing poverty rate. William Hansen argues, for instance, that 'the Boko Haram phenomenon...can only be understood as a reaction to more than a half century of corruption, venality, poverty, and abuse by the state predator class' (Hansen 2017:552). This view is echoed by Paul Rogers, a global security expert. In a briefing for the Oxford Research Group, Rogers attributes the growth of Boko Haram to three specific factors: 'the relative economic neglect of the Moslem north, a country-wide issue of very serious divisions of wealth and poverty (in spite of the oil wealth of the Delta), and an endemic problem of corruption, especially within the political system' (Rogers, 2012:2). Other authors have pointed to factors such as identity conflict arising from Nigeria's complex multi-religious/ethnic composition (Loimeier. 2012; Oyeniyi, 2014), modernisation strain (Idowu, 2013), and increase in rent-seeking behaviours (Gourley, 2012), as possible causes of the campaign of violence by Boko Haram.

Prior to its evolution into a terrorist organisation, Boko Haram's activities were perceived to be a localised problem and largely ignored by Nigerian authorities. However, in 2009 it embarked on a campaign of violence against security forces during which its leader, Mohammed Yusuf, was captured and, according to John Campbell, a former United States ambassador to Nigeria, murdered by the Nigerian army (Campbell, 2011). Contrary to expectations that Yusuf's death would curb the growth of the group, it appears that it marked a turning point for Boko Haram. Onapajo and Uzodike, (2012:24-25), for example, argue that 'the government's mishandling of the group's terrorist activities by the summary execution of its leader, Mohammed Yusuf, and the arrant use of force on its members, intensified the belligerence of the Boko Haram group'. After a short period of inactivity, following Yusuf's death, the group re-emerged more radical and embarked on a mission to propagate an Islamic ideology through a campaign of violence against the Nigerian state.

Officially known as Jama'atu Ahlissunnah lidda'awati wal Jihad, meaning 'people committed to the propagation of the prophet's teachings and Jihad', the group's best known label, 'Boko Haram', implies 'Western education is sacrilege' in the Hausa language, the most widely spoken language in northern Nigeria. The label reflects the group's commitment to hard-line Islamic principles and deep-seated hatred of Western way of life. The label is a media construct that resonates 'mainly because the public prefers it partly as a way of ridiculing the group and partly because it seems to fit into the group's outward ideological outlook' (Abubakar (2012:98). The group, however, has challenged this view, and blames what it refers to as 'the infidel media' for popularising the label. Boko Haram, a spokesperson for the group said, does not mean "Western Education is a sin" rather:

Boko Haram actually means 'Western Civilisation' is forbidden. The difference is that while the first [Boko Haram] gives the impression that we are opposed to formal education coming from the West... which is not true, the second affirms our belief in the supremacy of Islamic culture (not Education), for 
culture is broader, it includes education but not determined by Western Education (Onuoha, 2012:2).

It is worth noting that the label Boko Haram has become so entrenched in public discourse that even the sect's representative, while disputing the title, used the label instead of the group's official name. The explanation confirms the view that the group's ideological position goes beyond opposition to Western way of life but as Weeraratne (2017:612) argues, it also 'calls for the destruction of modern political, social and economic institution... and on the application of Sharia law....' Their application of violent techniques such as kidnappings, beheadings, and suicide bombings, including the use of improvised explosive devices and vehicle-borne improvised devices on both military and civilian targets are, therefore, in pursuance of these objectives. In sum, the Boko Haram label and other popular tags used in narratives about the group convey nuanced messages about the organisation and what it stands for.

Boko Haram's campaign of violence has generated a variety of labels (words and phrases) in narratives about the group and these are employed by different political actors in their bid to define the organisation, identify its root causes, and/or offer probable solutions. This research seeks to identify key actors in the Boko Haram discourse in four Nigerian national newspapers; to identify labels used to describe the group in the selected publications, and finally, to map the identified labels to the actors who employ them. Our study presupposes that the labels employed can be seen as reflections of Nigerian politics, which is marked by geo-ethno-religious cleavages and corruption, and also as a manifestation of the complexity of global terrorism.

\section{The politics of labelling}

Conventional understanding of labelling focuses on deviancy and how people who defy moral boundaries in society are treated as 'outsiders' and labelled as 'deviants' (Becker, 1963). For the purpose of this study, labelling is understood as 'an intrinsic component of human agency (Moncrieff and Eyben, 2007:20) and labels are understood as artefacts embedded in public discourse. Labelling, as Monccrieff and Eyben argue, involves 'insidious dimensions of power, where authoritative 'scientific' technique' can be used to depoliticise political processes (2007:19). Although their focus was in relation to welfare claims, their arguments are pertinent and applicable to other contexts of labelling. From this perspective, labelling can be seen as a negotiated political process driven by power because it reinforces political power structures. For instance, 'widespread use of subjective and vague terminology' could influence public perception, opinion and policy (Sexton, 2017:35). Put differently, some sets of actors can exercise power by imposing labels on situations and people in ways that can have significant implications. Labels can, therefore, be wielded as a weapon of power by political actors, and used as a means of legitimising or delegitimising other invested actors, thereby serving as a tool in the othering process.

Labels, in this study, refer to specific words used by political actors in media narratives in reference to Boko Haram. As Entman notes, words used consistently in media narratives convey particular meanings over time (Entman, 1991). This study adopts the functionality perspective of labelling, which focuses on the understanding 
that 'through the labelling process policy makers, willingly or unconsciously, shape reality according to their ideology and interest' (Broek, 2017:122). It is crucial to understand that although labels may appear neutral and objective, they are valueladen. 'Labels are not simply a number of isolated qualifications. For labels to be effective (credible, taken to be reliable reflections of part of reality), they have to form part of a chain of rational arguments: the appearance of rationality gives these labels the aura of objectivity' (Broek, 2017:122). Thus, labels have to be seen to be strategically chosen and embedded in narratives to convey a particular understanding of the discourse in question.

As mediating agents, and through their capacity to interact directly and indirectly with the powerful as well as the powerless, the media perform a vital role in the labelling process. They can identify and magnify and conversely ignore and downgrade certain labels. The power to name is critical because it ascribes an identity to the named and subject to the context, it determines the parameters for public perception of the named. When labels become acceptable, they legitimise action. By depicting a group as a terrorist organisation, those who have the power to name reconstruct the group's identity and convey a particular message about it. Labels do not just describe things, they make a judgement. This is particularly pertinent in the analysis of media framing of terrorism. A Martha Crenshaw noted:

It is clear from surveying the literature of terrorism, as well as the public debate, that what one calls things matters. There are few neutral terms in politics, because political language affects the perceptions of protagonists and audiences, and such effect acquires a greater urgency in the drama of terrorism. Similarly, the meanings of the terms change to fit a changing context (Crenhaw, 1995:7).

Labelling can, as a result, systematically direct attention to specific acts and identity markers. In this context, labels used by self-validating sources such as government spokespersons and even the media constitute highly rated information. For example, when the US House of Representatives Subcommittee labelled Boko Haram a terrorist group, media outlets reported the labelling without further obvious attempts to confirm the assertion. As primary definers, the politicians established the parameters for further discussion of the group and its potentials to attack the US interests and mainland. The labels utilised by members of the Committee legitimised and reinforced their recommendations and official positions on how best to tackle the Boko Haram problem. Against this backdrop, the mass media serve a 'hegemonic function in manufacturing public consent for counterterrorism policy and official frames for terrorism discourse by preferential disclosure of official information and agendas at the expense of other perspectives' (Crelinsten, 1989:320).

\section{METHODOLOGY}

This study employs a qualitative content analysis of data extracted from four national newspapers in Nigeria: The Guardian, The Punch, Daily Trust, and Leadership. The papers were selected to reflect the Nigerian press ecology, which is dominated by two publishing hubs in the north and south. The Guardian newspaper, which is regarded as Nigeria's flagship/elitist newspaper, and The Punch, which is deemed to be the most widely read newspaper in the country are published in the southern hub while the Daily Trust and Leadership newspapers are published in the northern hub. In 
addition, these two publications are widely circulated in the northern part of the country, and are regarded as 'the voice of the north'. The inclusion of papers from different parts of the country allowed for a balanced view of the coverage, while the overall combined coverage by the selected newspapers ensured a robust account of the key actors and labels utilised in discussions about Boko Haram.

The study set out to answer three key questions:

a. Who are the key political actors in the Boko Haram discourse in the selected national newspapers?

b. What were the dominant labels in the coverage of Boko Haram in the selected newspapers?

c. Which labels were utilised by the identified actors?

The time frame for this study covers the months of January and March 2017 . These were selected because there were no major Boko Haram attacks, which could have resulted in what-a-story moments, and possibly influenced the results of the study. Furthermore, during these months, the country, especially the Federal Government, led by President Muhammadu Buhari, and the Nigerian military, was in a celebratory mood over gains scored against Boko Haram. In his new year's speech to the nation, the president touted the success of his administration in ousting Boko Haram from Sambisa forest, a former game reserve that had been converted into a staging area for the sect. This speech triggered debates about the possible demise of Boko Haram, and sparked several responses from different political actors.

Data for analysis were mined using the keywords: Boko Haram, 'B'Haram', and Abubakar Shekau. B'Haram is an abbreviated term used in all the newspapers to represent Boko Haram; and Abubakar Shekau is the factional leader of the group and frequently mentioned in reference to the group. A total of 982 articles were identified as being relevant for analysis with The Guardian accounting for 279; The Punch 188; Daily Trust 236; and Leadership 279 articles. The coding instrument designed for the study comprised descriptive and conceptual variables. The descriptive variables included the name of the newspaper, date, source/byline of the article, occasion for the report, and type of article (news, news analysis, editorial, interview, column/opinion, and other) while the conceptual variables consisted of two categories, the main actor in the article and the word/phrase used to describe Boko Haram.

\section{Results}

Eighty-five percent of the articles examined across the newspapers were written by staff writers or the papers' own sources. About sixty percent of the stories in The Guardian and The Punch were news stories, while 36\% and $44 \%$ of stories in the Daily Trust and Leadership newspapers were column/opinion pieces. Most of the stories were reports of counterinsurgency operations embarked upon by the Nigerian military.

\section{Research Question One: Actors}

The first research question focused on the identity of key political actors in the coverage of Boko Haram by the selected newspapers. Political actors are narrowly defined in this article as those individuals or organisations who actively or aspire to influence political processes and policies through institutional or organisational structures (McNair, 2011). Ten unique categories of actors were identified, and are 
here listed according to their number of cumulative mentions across the four newspapers: The Nigerian military $(\mathrm{N}=209)$, the federal government $(\mathrm{N}=187)$, political figures $(\mathrm{N}=165)$, interest groups $(\mathrm{N}=105)$, non-partisan figures/religious figures $(\mathrm{N}=96)$, international organisations $(\mathrm{N}=69)$, Boko Haram $(\mathrm{N}=62)$, Victims $(\mathrm{N}=24)$, Academia $(\mathrm{N}=18)$, and the Media $(\mathrm{N}=16)$. These results indicate that the Nigerian military and the federal government, represented by the president and his appointees, were the most powerful voices in the discussion about the group. Political actors clearly identified as belonging to a political party, such as the People's Democratic Party (PDP) or the All Progressives Congress (APC); interest groups such as the Bring Back Our Girls (BBOG) group, and other civil rights movements also dominated the debate about Boko Haram. While the military was the most common type of source in all news stories, the federal government dominated the coverage of the group by the Daily Trust newspaper ( $\mathrm{N}=58)$. Given that most of the stories were straight news pieces, the media organisations had limited spaces (editorials) to label the group, and thus the newspapers emerged as the least active participant. However, this does not necessarily translate to a passive status.

\section{Research Question Two: Labels}

Twenty-four unique labels were identified: "terrorists", "insurgents", "Islamists", "militants", "jihadists", "Islamist militants/militant Islamists", "radical Islamists", "Islamic insurgents", Islamic sect", "fighters", "extremist/religious extremist", "Islamic fundamentalists", "terrorist group/terrorist sect", "fugitives", "bandits", "criminals/criminal elements", "common enemy", "murderers", "enemies of the state", "religious bigots", "rampaging marauders", "satanic elements", "hate mongers", and "merchants of death". Looking at the table, it is apparent that the labels "terrorist" $(\mathrm{N}=417)$, and "insurgents" $(\mathrm{N}=272)$ were employed more frequently than others.

Table I

\begin{tabular}{|c|c|c|c|}
\hline The Guardian & The Punch & Daily Trust & Leadership \\
\hline Terrorists $(\mathrm{N}=256)$ & Insurgents $(\mathrm{N}=46)$ & Terrorists $(\mathrm{N}=54)$ & Terrorists $(\mathrm{N}=72)$ \\
\hline Insurgents (N=138) & Terrorists $(\mathrm{N}=35)$ & Insurgents $(\mathrm{N}=33)$ & Insurgents $(\mathrm{N}=55)$ \\
\hline Islamists $(\mathrm{N}=29)$ & Fighters $(\mathrm{N}=6)$ & $\begin{array}{l}\text { Terrorist } \\
\text { group/terrorist } \\
\text { sect }(N=7)\end{array}$ & $\begin{array}{l}\text { Criminals/criminal } \\
\text { elements }(N=4)\end{array}$ \\
\hline Militants $(\mathrm{N}=22)$ & Militants $(\mathrm{N}=4)$ & Fighters $(\mathrm{N}=6)$ & Fighters $(\mathrm{N}=4)$ \\
\hline Jihadists $(\mathrm{N}=21)$ & $\begin{array}{l}\text { Extremists/religious } \\
\text { extremists }(\mathrm{N}=2)\end{array}$ & Bandits $(\mathrm{N}=2)$ & $\begin{array}{l}\text { Enemies of the } \\
\text { state }(\mathrm{N}=2)\end{array}$ \\
\hline $\begin{array}{l}\text { Islamist militants/ } \\
\text { militant Islamists } \\
(\mathrm{N}=7)\end{array}$ & $\begin{array}{l}\text { Islamic } \\
\text { fundamentalists } \\
(\mathrm{N}=1)\end{array}$ & $\mathrm{V}=2)$ & $\begin{array}{l}\text { Religious bigots } \\
(\mathrm{N}=1)\end{array}$ \\
\hline $\begin{array}{l}\text { Islamist extremists } \\
(\mathrm{N}=4)\end{array}$ & $\begin{array}{l}\text { Terrorist group } \\
(\mathrm{N}=1)\end{array}$ & Criminals $(\mathrm{N}=1)$ & $\begin{array}{l}\text { Rampaging } \\
\text { marauders }(\mathrm{N}=1)\end{array}$ \\
\hline $\begin{array}{l}\text { Radical Islamists } \\
(\mathrm{N}=2)\end{array}$ & Islamists $(\mathrm{N}=1)$ & $\begin{array}{l}\text { Common enemy } \\
(\mathrm{N}=1)\end{array}$ & $\begin{array}{ll}\text { Terrorist } & \text { group } \\
(\mathrm{N}=1) & \\
\end{array}$ \\
\hline $\begin{array}{l}\text { Islamic insurgents } \\
(\mathrm{N}=1)\end{array}$ & & Murderers $(\mathrm{N}=1)$ & Militants $(\mathrm{N}=1)$ \\
\hline Islamic sect $(\mathrm{N}=1)$ & Fugitives $(\mathrm{N}=1)$ & Islamists $(\mathrm{N}=1)$ & Bandits $(\mathrm{N}=1)$ \\
\hline
\end{tabular}




\begin{tabular}{|l|l|l|l|}
\hline & & $\begin{array}{l}\text { Islamic militants } \\
(\mathrm{N}=1)\end{array}$ & $\begin{array}{l}\text { Satanic elements } \\
(\mathrm{N}=1)\end{array}$ \\
\hline & & $\begin{array}{l}\text { Hate mongers } \\
(\mathrm{N}=1)\end{array}$ \\
\hline & & $\begin{array}{l}\text { Merchants of } \\
\text { death }(\mathrm{N}=1)\end{array}$ \\
\hline
\end{tabular}

\section{Research Question Three: Labels by actors}

As previously noted, ten categories of political actors were identified in the discussion about Boko Haram during the time frame of the study. The Nigerian military, the federal government, political figures, and interest groups for the most part employed two key labels, "terrorists", and "insurgents", in their description of the sect. The international organisations category consists of organisations that are not domiciled in Nigeria, and includes bodies like the International Red Cross Society, Amnesty International, and Médecins Sans Frontières (MSF)/Doctors Without Borders and international news agencies. International sources mostly used two closely related labels, "Islamists" and "jihadists".

The category of story sources tagged non-partisan/religious figures include political actors who are not clearly affiliated with any political party, and representatives of religious groups. Results from this study showed a marked difference between the labels used by this category, especially those affiliated with either Christianity or Islam, the dominant religious groups in the country. For instance, whereas the national coordinator of the Muslim Media Watch Group of Nigeria (MMWG), Alhaji Ibrahim Abdullahi, described Boko Haram as "satanic elements"; the General Secretary of the Christian Association of Nigeria (CAN), Dr. Musa Asake, called Boko Haram, "an Islamic fundamentalist sect."

The media category includes the selected national newspapers themselves (The Guardian, The Punch, Daily Trust, and Leadership), acting in their capacity as political actors. To identify their positions on the issue, this phase of the study examined the editorial columns, and stories written by the newspapers' editors, with the objective of locating the labels applied by the newspapers in their narratives about the sect. Overall, there were very few editorials in which Boko Haram was clearly labelled during the timeframe of the study. For instance, although the search parameters were located in four editorials in the Daily Trust newspaper, no definitive labels were used in association with the sect. Yet, as previously noted in response to research question two, most of the political actors named in these newspapers applied labels closely associated with crime/criminality. Regarding the other newspapers, findings show that while The Guardian and The Punch utilised the labels, "jihadists" and "Islamists" in reference to the sect, Leadership employed the phrase "rampaging marauders" in their description of the group.

Although members of the academic community ranked lower in terms of participation in the Boko Haram discourse, they applied similar labels as those utilised by the dominant political actors. For instance, while speaking at a symposium in Lagos State, an annual event held to deliberate on national concerns, Dr. Dele Ashiru of the Department of Political Science, University of Lagos, said: 'Padding had encouraged armed bandits to have the effrontery now to challenge the authority of the state. That is why we have Boko Haram insurgents, Niger Delta militants, IPOB due to 
deliberate and criminal neglect of the need of the minorities and the masses by the political class (Olumide, 2017, para. 5). The use of the 'insurgent' label echoed the military's framing of Boko Haram.

The category that consisted of Boko Haram and Victims, though visible in the coverage, were silent in terms of distinctive labelling. They were recognised as actors because Boko Haram engaged in what Rapoport (1977) describes as 'the politics of atrocity' and the victims, (those who were directly affected by Boko Haram's activities), were directly represented in discussions about the group. However, there were no clear cases of labelling on their part.

\section{Discussion}

The labels identified in the narratives can be categorised under three broad headings: contested, ideological and profit-driven labels. Contested labels include 'Terrorist', 'terrorist group', Terrorist sect', 'militant', fighters' and 'insurgents'. These labels were used mainly by political actors and interest groups. Non-partisan and religious actors, international organisations and the media used ideological labels. These labels were framed around religion and include 'Islamists', 'jihadists' and 'Islamic fundamentalists'. Profit-driven labels are those that were framed around criminality and these were used by the newspapers published in the northern hub and political leaders.

To contextualise the lexical choices of the various actors, it is helpful to situate this discussion within a wider context of the debate about terrorism and the role of the media. Terrorism is a contested concept. As a result, the definitional debate has critical consequences on how the media construct knowledge about the subject. Richard Jackson, for example, describes terrorism as 'a highly emotive and divisive concept which different scholars and societies have often understood in very different ways' (2008:25). How terrorism is understood in a society has direct bearing on how people labelled as terrorists are treated. In Nigeria the 'Terrorism (Prevention) Act, 2011, states that an:

"Act of terrorism" means an act which is deliberately done with malice, aforethought and which: may seriously harm or damage a country or an international organisation [and] is intended or can reasonably be regarded as having been intended to unduly compel a government or international organisation to perform or abstain from performing an act (Centre for Laws of the Federation of Nigeria).

Other manifestations of acts of terrorism identified in the Act include seriously intimidating a population, seriously destabilising or destroying political, constitution, economic or social structures of a country or an international organisation, intimidation, coercion, kidnapping, destruction to a government or public facility, a transport system, an infrastructure facility, including an information system, seizure of an aircraft, ship or other means of public or goods transport, the manufacture, possession, acquisition, transport, supply or use of weapons, explosives or of nuclear, biological or chemical weapons, as well as research into, and development of biological and chemical weapons without lawful authority. 'The release of dangerous substance or causing of fire, explosions, or floods, the effect of which is 
to endanger human life, interference with or disruption of the supply of water, power, or any other fundamental natural resource, the effect of which is to endanger human life' (Centre for Laws of the Federation of Nigeria).

This definition is striking in its broadness and to some degree, its vagueness and especially in its failure to recognise terrorism as a political concept. As Bruce Hoffman, a leading scholar on terrorism, explains, terrorism is 'fundamentally and inherently political. It is also ineluctably about power: the pursuit of power, the acquisition of power, and the use of power to achieve political change. Terrorism is thus violence - or, equally important, the threat of violence - used and directed in pursuit of, or in service of, a political aim' (Hoffman, 2006:2). The definition of terrorist act in the Nigerian context frames out the political undertone of terrorism but makes morality salient. Conceptualised as an action informed by malice and aforethought, the definition rejects common understanding of terrorism as a particular type of violence that is designed to create a climate of extreme fear and which is directed at wider audience beyond the immediate victims and often used 'primarily, though not exclusively, to influence the political behaviour of governments, communities or specific social groups (Wilkinson, 1997:51). Essentially, terrorism is a communicative act because it 'instrumentalises its victims ....and the victims of terrorism are chosen for symbolic reasons. (Jackson, 2008: 29).

As a form of political communication, terrorism depends on the media for the magnification of violent acts. Thus, terrorists depend on the media for their own communicative purposes (Crelinsten, 1989). Brigitte Nacos argues that people who commit political violence 'understand their deeds as a means to win media attention and news coverage for their actions, their grievances, and their political ends' (Nacos, 2002:10). To Schmid and de Graaf, immediate victims of terrorism are 'merely instrumental, the skin of a drum beaten to achieve a calculated impact on a wider audience. As such, an act of terrorism is in reality an act of communication' (as cited by Nacos, 2002: 10). It is in this context that L. John Martin argues that terrorists exploit the media for tactical and strategic goals to gain publicity for their actions (Martin, 2008).

From the foregoing, it is apparent that the definition of act of terrorism as outlined by the Nigerian Terrorism Act leans more towards crime and this is reflected in some of the labels used in the framing of the group in the Nigeria press. It is clear that the labels used by key political actors in their description of Boko Haram are indicative of the interplay of power in the sense that the tags were capable of influencing public perception. It is interesting to note that the military and the federal government used 'terrorists' and 'insurgents' labels to identify Boko Haram members. Hoffman argues that the word 'terrorism' is a pejorative term. Moreover, 'it is a word with intrinsically negative connotations that is generally applied to one's enemies and opponents, or those with whom one disagrees and would otherwise prefer to ignore' (Hoffman, 2006:23). Brian Jenkins has observed that the 'use of the term implies a moral judgement; and if one party can successfully attach the label terrorist to its opponent, then it has indirectly persuaded others to adopt its moral viewpoint' (Jenkins, 1975, as cited by Hoffman, 2006: 23).

The use of the contested labels did not associate Boko Haram with radical Islam, a cause that the group uses to justify its existence and activities. Moreover, the use of 
these labels legitimised actions taken to contain the group. For instance, in a Daily Trust article, Brigadier General Sani Usman, the Nigerian Army spokesman, warned communities in the northeast region of the country against colluding with 'terrorists', as he called members of Boko Haram, and warned that it was 'a grievous mistake and criminal offence to continue to shield or harbour any known Boko Haram terrorist in their midst (Mutum, 2017, p. 3). The success of the military in containing the group was highlighted by political actors in the federal government category as represented by a senior special assistant to the president, who noted the:

Concrete achievements of the Buhari administration in the past two or so years, including the undeniable fact that the Boko Haram terrorists have been significantly crippled militarily, because they no longer have the capability to invade and occupy towns and villages unchallenged by the country's reinvigorated and motivated military personnel, (Wakill, 2017, p. 3).

Similarly, Yusuph Olaniyonu, Special Adviser on Media Publicity to the Senate President, in a statement marking the 2017 new year's celebration, described Boko Haram as insurgents: "It is a thing of joy to celebrate the New Year in an atmosphere of peace and security. For one thing, the people of the Northeast and indeed across the country are celebrating without fear of attacks from insurgents .... (Egulefu, Agba \& Nda-Isaisah, 2017, p. 6).

While the labels used by the military and the federal government distanced Boko Haram from Islam, international organisations, including news agencies, used two labels that clearly located the group within the Islamic milieu. The two related labels in use were "Islamists" and "jihadists". These labels are unequivocally ideological. In a story published in The Guardian on January 1, 2017, the newspaper described a terrorist attack as bearing 'the hallmark of Boko Haram Islamists who are notorious for using suicide bombers, mostly women and young girls, in attacking civilian targets.... Saturday's attack came a week after Nigerian President Muhammadu Buhari said the jihadist group had been routed from Sambisa forest, its last stronghold in Borno state (AFP, 2017, para. 4 \& 13). In another instance, following an accidental bombing of a camp for internally displaced people, the Médecins Sans Frontières (MSF) criticised the military for 'a botched air strike on Boko Haram Islamists in Nigeria that killed at least 52 civilians' (AFP, 2017, para. 1). The organisation described the far north of Borno state, where the camp was located as the epicentre of the jihadists' insurgency (AFP, 2017, para. 3). The labels contradicted the official understanding of terrorism in Nigeria and illustrated how the international organisations applied a Western framework of meaning to the situation.

For the non-partisan/religious figures, the labels commonly used were remarkably different but similar in the nuances. To a Muslim leader, members of Boko Haram were "satanic elements" who in 2009 started 'devilish attacks' which led some people to believe that they were 'Muslims waging war against the Christians'. This view also distanced the group from its Islamic root but located it within broader context of evil. In contrast, a Christian leader described Boko Haram's attacks on the church in Nigeria as:

A systematic genocide and persecution through the instrumentality of the Islamic fundamentalist sect, Boko Haram, leading to the killing of thousands of 
Christians and destruction of hundreds of churches, and over 50,000 houses, the current unprecedented onslaught against Christians in Southern Kaduna by the Islamic fundamentalists disguising as Fulani herdsmen under the watch of the Kaduna State Governor, Mallam Nasir el-Rufai, and President Muhammadu Buhari has reached an alarming stage. (Olokor, 2017:12. The Punch).

Similar to the international organisations, the Christian community associated Boko Haram with Islamic ideology.

The discussion so far illustrates how the media play a critical role in the discursive practices that results in labels. As Richard Jackson notes, 'although acts of violence are experienced as brute facts, the wider cultural-political meaning of those acts as 'terrorism' for example, is decided through symbolic labelling, social agreement and a range of intersubjective practices' (Jackson, 2008: 27). The labels identified in this study conveyed a particular understanding of the Boko Haram problem. The labels either connected Boko Haram to Islam or distanced it from its ideological foundation. Framing Boko Haram's activities as crime distanced the group from its ideological roots. Furthermore, the use of profit-driven labels implied that members of Boko Haram were driven by economic deprivation to engage in acts of terrorism. Adopting a militarised counterinsurgency approach was therefore inappropriate. This view was evident in an editorial in Leadership in which the paper alluded that the government was wasting money on rehabilitation and deradicalisation in its fight against 'the rampaging marauders called Boko Haram' (Leadership editorial, 2017, p. 3).

As noted earlier, newspapers published in the southern hub used labels that aligned Boko Haram with its Islamic roots. The Guardian identified it as jihadist group while The Punch labelled it Islamist. The lexical choices of these two newspapers illustrate the intersubjective journalistic practice of using condensational symbols to convey messages. In this case, the discursive practices in use reflect socio-political and geoethno cleavages in Nigerian politics. The labels reflect political and ethnic frameworks of meanings. Leadership, a newspaper identified with the north, the heartland of the Moslem faith, distanced Boko Haram from Islam while The Guardian and The Punch, which are published in the south, reinforced the ideological connection. Framing members of Boko Haram as Islamic fundamentalists reveal ethno-political divides embedded in Nigerian politics and regional media practices. The labelling of Boko Haram as a jihadist/Islamist organisation transcends editorial choices, it is an expression of moral judgment.

On a more general note, the selection of labels used to frame Boko Haram point to a disconnect between key political actors and voices in the terrorism discourse in Nigeria. The contradictions in the application of the labels distort public perception and probably undermines effort to tackle it because of a lack of shared understanding of the Boko Haram problem.

\section{Conclusion}

This study explored the politics of labelling in the construction of narratives about Boko Haram in four Nigerian national newspapers. It identified key political actors and the different labels the actors use to frame the group in newspaper reports. The interpretative framework used by self-validating political actors and the newspapers 
underscore a particular understanding of the group. It was clear that some labels obscured or demystified the underlying causes of the Boko Haram problem while some justified policies and actions taken against Boko Haram. Some of the labels diverted attention from critical issues associated with Boko Haram, for example, corruption, because fighting 'terrorism' has become an economic problem and an enterprise with a big price tag. The federal government, for example, claims that about $20 \%$ of the annual budget is expended on security (Elden, 2014).

The use of 'criminal' label was a denial of the political and religious dimensions of Boko Haram. Viewed only from an economic deprivation perspective, Boko Haram would be like any other insurgent and self-determination group. While the economic hardship in northern Nigeria could have created a conducive environment for grievance, leaders of the group have exploited the situation to push for a religious agenda. The use of the criminal label can, therefore, be seen as a deliberate rejection of the values and ideology associated with the group. Beyond the denial of ideological foundation of Boko Haram, the use of the 'criminal' label also suggested a rejection of reality. Boko Haram is not a typical criminal gang, it is a group that utilises violence to communicate its message. While criminals may use violence as a tool, their motivation is always self-centred and for personal gain. 'Moreover, unlike terrorism, the ordinary criminal's violent act is not designed or intended to have consequences or create psychological repercussions beyond the act itself.... Perhaps most fundamentally, the criminal is not concerned with influencing or affecting public opinion; he simply wants to abscond' with the loot (Hoffman, 2006:36-37). Besides, unlike a common criminal, a terrorist believes and is committed to a cause. In the case of Boko Haram, the goal is the establishment of a Caliphate and implementation of Sharia in northern Nigeria.

The analysis presented here illustrates the extent to which ethno-religious divides embedded in Nigerian politics and regional media practices influence the framing of a group that poses threat to the stability of the country. This study reinforces the contested nature of terrorism and how the media reflect the absence of definitive understanding of the concept. It also highlights how journalistic practice of labelling reflects political and geo-ethnic cleavages in Nigerian politics and media ecology.

\section{References}

Abubakar, Abdullahi (2012), 'The media, politics and the Boko blitz' Journal of African Media Studies, 4 (1): 97-110

Agence France Presse (AFP) (2017a), '10-year-old girl used as human bomb in Maiduguri', The Guardian, 1 January, https://guardian.ng/news/10-yearoldgirl-used-as-human-bomb-in-maiduguri/. Accessed 23 March 2018.

(2017b), 'Scramble to treat wounded IDPs after airstrike', The Guardian, 18 January, https://guardian.ng/news/scramble-to-treat-wounded-idpsafterairstrike/. Accessed 23 March 2018.

Becker, Howard. (1963). Outsiders: Studies in the Sociology of Deviance. New York: Free Press 
Broek, Hans-Peter van den (2017) Labelling and legitimisation: Justifying political violence in the Basque Country. Terrorism and Political Violence, 29:1, 119-136 Campbell, John (2011). Nigeria: Dancing on the Brink. Blue Ridge Summit, PA: Rowman \& Littlefield Publishers, Inc.

Centre for Laws of the Federation of Nigeria, https://nass.gov.ng/document/ download/5944. Accessed 6 March 2019.

Chothia, F. (2016), 'Who are Nigeria's Boko Haram Islamists?', BBC, 24 November, http://hud.ac/ejq. Accessed 6 March 2019.

Crelinsten, Ronald (1989) Terrorism and the media: Problems, solutions, and counterproblems. Political Communication, 6:4, 311-339

Crenshaw, Martha, ed. (1995). Terrorism, Legitimacy, and Power: The Consequences of Political Violence, Middletown: Wesleyan University Press

Egbulefu, T., Agba, G. and Nda-Isaiah, J. (2017), 'PMB promises frontal action on Southern Kaduna crisis', Leadership, 1 January, p. 6

Elden, Stuart (2014) 'The geopolitics of Boko Haram and Nigeria's 'war on terror', The Geographical Journals, 180:4, 414-425

Entman, Robert M. (1991). "Framing U.S. Coverage of International News: Contrasts in Narratives of the KAL and the Iran Air Incidents," Journal of Communication 41(4):6-27

Entman, Robert M. (1993). Framing: Toward clarification of a fractured paradigm. Journal of Communication 43 (4): 51-8

Gourley, S. M. (2012), 'Linkages Between Boko Haram and al Qaeda: A Potential Deadly Synergy', Global Security Studies, 3:3, pp. 1-14.

Hakeem Onapajo \& Ufo Okeke Uzodike (2012) Boko Haram terrorism in Nigeria, African Security Review, 21:3, 24-39, DOI: 10.1080/10246029.2012.687693

Hansen, William. (2017). Boko Haram: Religious radicalism and insurrection in northern Nigeria. Journal of Asian and African Studies, 52:4, 551-569. doi:10.1177/0021909615615594

Herskovits, J. (2012), 'In Nigeria, Boko Haram is not the problem', New York Times, http://hud.ac/ekb. Accessed 6 June 2019.

Hoffman, Bruce. (2006). Inside Terrorism, New York: Columbia University Press http://hud.ac/ej4 (Last accessed 13 June 2018)

Idowu, Amos Adeoye (2013). Security laws and challenges in Nigeria: The Boko Haram Insurgency, Journal of Applied Security Research, 8:1, 118-134, DOI: 10.1080/19361610.2013.738395 
Jackson, Richard. (2008). An Argument for Terrorism. Perspectives on Terrorism, Volume 11, Issue 2: 25-32

Labott, Elise and Botelho, Greg (2013). 'U.S. designates Boko Haram, its offshoot as terrorist organisations', CNN, November 13, http://hud.ac/ej5

Leadership Editorial (2017), 'Our stand', Leadership, 8 March, p. 3.

Loimeier, Roman. (2012). Boko Haram: The development of a militant religious movement in Nigeria. African Spectrum, 2(3), 137-155

Martin, L. John, (2008). The media's role in international terrorism. Terrorism: an international journal, 8:2: 127-146

McNair, Brian (2011). An introduction to Political Communication. Routledge: London and New York

Moncrieffe, Joy and Eyben, Rosalind (eds.) 2007. The Power of Labelling: How People are Categorized and Why It Matters. Earthscan: London

Mutum, Ronald. (2017, March 17). Army warns against shielding insurgents. Daily Trust., p.3

Nacos, Brigitte (2002) Mass-Mediated Terrorism: The Central role of the media in terrorism and counterterrosim. Lanham: Rowman\& Littlefield Publishers

Olokor, F. (2017), 'Buhari's silence, endorsement of Kaduna killings says CAN', The Punch, 2 January, p. 12.

Olumide, Seye (2017, January 2). 'Varsity teachers, envoy ask Buhari, APC to tackle budget padding'. The Guardian. Retrieved from https://guardian.ng/news/varsityteachers-envoy-ask-buhari-apc-to-tackle-budget-padding/ Accessed 10 January 2017

Onuoha, F. (2012), 'Boko Haram: Nigeria's extremist Islamic sect', Al Jazeera Centre for Studies, http://studies.aljazeera.net. Accessed 6 March 2019.

Oyeniyi, Bukola Adeyemi (2014). One voice, multiple tongues: Dialoguing with Boko Haram, democracy and security, 10:1, 73-97, DOI: 10.1080/17419166.2013.858031

Rapoport, D. (1977), 'The politics of atrocity', in Y. Alexander and S. M. Finger (eds), Terrorism: Interdisciplinary Perspectives, New York: John Jay Press.

Rogers, P. (2012), 'Nigeria: The generic context of the Boko Haram violence', London: Oxford Research Group.

Schmid, Alex P. (2005). Root causes of terrorism: Some conceptual notes, a set of indicators, and a model. Democracy and Security 1 (2): 127-36. 
Schmid, Alex P., de Graaf, Janny, (1982). Violence as Communication: Insurgent Terrorism and the Western News Media. Beverly Hills, Calif.: Sage Publications

Sexton, Mark (2017). 'What's in a name? Proposing new typologies for 'foreign fighters'. The RUSI Journal, 162:5, 34-43

U.S. Homeland Security Committee Report (2011), Boko Haram - Emerging Threat to the U.S. Homeland, U.S. Homeland Security Committee Report, U.S. House of Representatives, Committee on Homeland Security, Washington D.C., https://www.hsdl.org/?view\&did=692849.

Accessed 6 March 2019.

Wakill, Isiaka. (2017, January 23). Presidency: Public officers now afraid to steal with impunity. Daily Trust, p.3

Walker, Andrew (2012). 'Special Report: What is Boko Haram?' Report 308, United States Institute of Peace, Washington DC, http://hud.ac/ej9 (Last accessed 14 June 2018)

Weeraratne, Suranjan (2017). 'Theorizing the Expansion of the Boko Haram Insurgency in Nigeria. Terrorism and Political Violence, 29:4, 610-634.

Wikinson, Paul (2007). The media and terrorism: A reassessment 'Terrorism and Political Violence, Vol.9, No.2 (Summer 1997), pp.51-64

Wilkinson, Paul. (1997). The media and terrorism: A reassessment. Terrorism and Political Violence, 9:2, 51-64. doi:10.1080/09546559708427402

\section{Biographical note}

Mercy Ette is a senior lecturer in Journalism and Media at the University of Huddersfield, UK. She holds a Ph.D. in Communication Studies from the University of Leeds. Her research focuses on journalism and conflict, media and democracy, gendered mediation, and political communication.

Sarah Joe is a doctoral student in Journalism and Media at the University of Huddersfield. Her research interests include framing analysis, social media and political communication.

Corresponding author: Mercy Ette: $\underline{\text { m.ette@hud.ac.uk }}$ 